\title{
What Factors Predict Need Achievement among Undergraduates in Nigeria?
}

\author{
Samuel E. Oladipo \\ Department of Counselling Psychology, Tai Solarin University of Education, Ijagun, Ijebu \\ Ode, Ogun State, Nigeria. \\ Email: kingola2001@yahoo.com
}

Beatrice I. Ajufo

Department of Counselling, National Open University, Lagos, Nigeria

Accepted: December 17, 2012 Published: January 26, 2013

Doi:10.5296/jsr.v4i1.3162 URL: http://dx.doi.org/10.5296/jsr.v4i1.3162

\begin{abstract}
This study investigated possible factors that predict need achievement among university undergraduates in Nigeria. Using convenient sampling method, a total of 420 participants were selected for the study. There were 153 male and 267 females. 334 were Christians, 81 Muslims, and 5 traditionalists. Of these, 69 were in their first year at school, 166, in their second year, 147, in their third year and 38 in their fourth year. Their ages ranged between 16-31years, mean age was 24.67 and a standard deviation of 23.14. Three hypotheses were tested and the results indicated that sex was not a significant predictor of students' need achievement ( $\mathrm{df}=418, \mathrm{t}=-.248, \mathrm{p}>.05$ ); however, institution of learning ( $\mathrm{df}=2, \mathrm{~F}=203.48, \mathrm{p}$ $<.05)$ and students' academic level ( $\mathrm{df}=3, \mathrm{~F}=32.76, \mathrm{p}<.05)$ were significant predictors of students' need achievement respectively. The findings indicate that students' gender has no influence on their need achievement motivation, however, students' institution and academic level have significant influence on their need achievement motivation, therefore, educators and policy makers need to pay attention to it in improving both the standard of education as well as the level of motivation among undergraduates.
\end{abstract}

Keywords: Tertiary institutions, Need achievement, Nigeria, Undergraduates, College of Education.

\section{Introduction}

Over the years, the concept of motivation has been seen to help in explaining why individuals with the same aptitude or intelligence perform differently on tasks. When people perform beyond their predicted capability, it is interpreted to be over-achievement. On the other hand, when they achieve below their predicted capability it is referred to as under-achievement. The 
same is true in the academic environment where students with same scholastic aptitude or intelligence perform differently on academic tasks. When students achieve beyond their predicted capability, teachers referred to it as over-achievement and when they achieve below predicted capability, it is termed as under-achieve. All these are pointers to the fact that students differ in the things that motivate them into achieving greater feats (i.e. achievement motivation). Need for achievement (N-Ach) refers to an individual's desire for significant accomplishment, mastering of skills, control, or high standards. It is related to the difficulty of tasks people choose to undertake. Achievement motivation as a widely researched topic has been an important issue for psychologists and individuals in the field of education because it has been correlated with academic self-concept (Marsh \& Ayotte, 2003), academic self-efficacy (Bong \& Skaalvik, 2003), personality traits (Mandel \& Marcus, 1988), developmental level (Guay, Marsh, \& Boivin, 2003), and gender differences (Mandel \& Marcus, 1988). Sex differences in achievement motivation have been studied widely (Meece, Glienke, \& Burg, 2006).

A look at the theoretical models of achievement motivation shows that need achievement has been related to students' future success, learning outcomes, their numerous choices, as well as their desire to engage in a behavior (Deci, Vallerand, Pelletier, \& Ryan, 1991). In academic settings, the interest in motivation is partly inspired by the notion that students' motivation, operationalized, e.g., as their competency beliefs and value beliefs, could be more malleable than their cognitive ability, and as such could prove to be a potential lead for the educational system for improving learning and achievement processes in students (e.g., Spinath, Spinath, Harlaar, \& Plomin, 2006).

Research on motivation has been on the increase over the past four decades. As a result, much has been learned about the nature of students' motivation. During the past half century, a variety of crucial motivational beliefs, values, and goals have been identified and examined (Wigfield, 1997). Some studies have focused on competence-related beliefs as a valuable measure of an individual's achievement motivation (Linenbrink \& Pintrich, 2002; Wigfield \& Eccles, 2002). Males and females were found to have different competence-related beliefs during childhood and adolescence (Wigfield \& Eccles, 2002). These beliefs also affect the student's motivation to succeed and achieve a goal.

Elizur \& Beck (1994) detected no special tendency for women to score higher than men on affective responses in achievement motive questionnaire (Elizur 1994). Their results support the view that gender differences in achievement motive are rooted in socialization processes rather than in basic differences between men and women. On the other hand, Nagarathanamma \& Rao (2007) found no significant difference between boys and girls with regard to achievement motivation level. Similar findings were reported by Kaushik \& Rani (2005). Along with other findings male students were found to be having a high achievement motivation while female students having a below average level of achievement motivation (Adsul, Kamble, \& Sangli, 2008).

Liu \& Zhu (2009) found significant differences in achievement motivations of male and 
female senior high school students, male students have higher achievement motivations than female students; the achievement motivations of students studying science and students studying arts have difference closely to significant difference.

Upadhyay \& Tiwari (2009) evaluated the effect of academic majors on achievement motivation of the students. Results showed students of science faculty had significantly higher achievement motivation in comparison to Social Science, Humanities and Commerce faculty, but it does not significantly differ from the vocational courses.

Fouladchang et al.(2009) with the purpose to investigate the effect of gender and grade level differences on goal orientations of undergraduate students in an Iranian university collected a sample of 302 Iranian students by random cluster sampling. It was found that males had a greater performance-approach goal orientation than females. Also, last graders reported higher scores on mastery goal orientation than first graders. There was no significant interaction effect of gender and grade level.

Salili (1996) investigated age, sex and cultural differences in achievement motivation. The study was conducted on British high school and Chinese students aged 13-55. Results revealed that Chinese high school students had significantly higher n-Ach scores than their British counterparts. Female subjects of both cultures had higher scores than males, although this difference was significant for British female subjects only.

It is on the aforementioned premise that the present study set out to look at how students' gender, institution and academic level would influence their level of need achievement motivation. It was hypothesized that there will be significant difference between the achievement motivation of male and female undergraduates and that institution and academic level will also significantly predict motivation among undergraduates. Three hypotheses were tested in this study:

1. Male students will be significantly higher on Need achievement motivation than their female counterpart.

2. Religious affiliation will significantly predict need achievement motivation among undergraduates.

3. Student's academic level will significantly predict their levels of need achievement motivation

\section{Method}

2.1. Design: - This study adopted a cross-sectional ex post survey research design

2.2 Participants: - Participants in the study were 420 undergraduates who were drawn from three (3) higher institutions in Southwestern Nigeria; there were 153 male and 267 females. 334 were Christians, 81 Muslims, and 5 traditionalists. Of these, 69 were in their first year at 
school, 166, in their second year, 147, in their third year and 38 in their fourth year. Their ages ranged between 16-31years with the mean age being 24.67 and standard deviation being 23.14

2.3. Sampling procedure: - samples were conveniently selected for participation in the study. Despite the adoption of convenient sampling method, participant's consent was got before requesting them to respond to the research instrument.

2.4. Instrument of data collection: - The McLelland 9-item nAch scale was the main instrument of data collection. It is in the likert format and the responses ranged between strongly agreed - strongly disagree, some items are in the reversed order. For this study, an Alpha reliability of .85 was established. A score above the mean on the scale indicates a high need achievement, while a score below the mean indicates a low need achievement motivation.

2.5. Procedure for data collection: - After obtaining permission from the appropriate authorities, study participants were approached and after seeking their consents the research instrument was administered on them. Participants completed and returned the questionnaires during their free periods; this was possible because the approximate time of response was 10minutes.

2.6. Statistical Analysis: - The SPSS version 17.0 was used in the analysis of the data collected. Hypothesis 1 was analysed with the student t-test for independent samples, while hypotheses $2 \& 3$ were analysed with the one way analysis of variance. The result is presented in the result section.

2.7. Results: - Three hypotheses were tested and the results indicated that sex was not a significant predictor of students' need achievement ( $\mathrm{df}=418, \mathrm{t}=-.248, \mathrm{p}>.05)$; however, institution of learning ( $\mathrm{df}=2, \mathrm{~F}=203.48, \mathrm{p}<.05$ ) and students' academic level ( $\mathrm{df}=3$, $\mathrm{F}=32.76, \mathrm{p}<.05$ ) were significant predictors of students' need achievement respectively.

\section{Discussion}

Two of the three hypotheses stated were confirmed, while one was rejected. In line with previous research findings by researchers like Elizur \& Beck (1994); Nagarathanamma \& Rao (2007) and Kaushik \& Rani (2005), this study found no significant difference in the need achievement motivation of male and female undergraduates. Although, Liu \& Zhu (2009) and Fouladchang et al.(2009) found significant differences in achievement motivations of male and female students, cultural variance and the population sampled may have accounted for the difference in findings as observed. In other words, it is inferred that both male and female students do not significantly differ in their level of achievement motivation.

However, result of analysis showed that university students are more motivated to achieve 
than college students. This may be due to the fact that there is a perceived (societal) preference for university graduates compared to college graduates (in the context where this present research was carried out). Many people believe that those who attend colleges and not universities are inferior to those who are in the university, therefore the college students themselves have a feeling that they are not yet where they aimed to be and they mostly have it in mind to go to the university.

In the same vein, students in their final grades in school were significantly higher in their need for achievement compared to students in lower grades. This could be as a result of the fact that the final year students are closer to graduation and may soon come to terms with the reality of being independent (sort of), they will soon begin the search for jobs in the labor market, and it is only logical to reason that they will sure desire a better experience after school. They would desire to get a good job and plan towards settlement, hence the high need achievement motivation that is manifested. This may not be the case in the lower grade students who may still be adjusting to school life or who may not have had an idea of what lies ahead of him after school.

\section{Conclusion}

It is concluded therefore that there is no significant difference between male and female university undergraduates' need achievement motivation. But significant differences exist based on institution of learning and grade level of students. It needs be mentioned however that there are a few limitations to this work. There are several other factors e.g. psychological, social, economic etc that may influence an individual's need achievement motivation, therefore a very strong recommendation may be impossible based on the few variables that were examined in this study. The convenient sampling procedure employed could also have been a limitation. Further studies can therefore pay attention to these limitations and expand the scope of the study in subsequent researches.

\section{References}

Adsul, R. K., Kamble, V., \& Sangli, K. W. (2008). Achievement Motivation as a Function of Gender, Economic Background and Caste Differences in College Students. Journal of the Indian Academy of Applied Psychology, 34, 323-327.

Bong, M., \& Skaalvik, E. M. (2003). Academic self-concept and self-efficacy: How different are they really? Educational Psychology Review, 15(1), 1-40.

Eccles-Parsons, J., Adler, T. F., Futterman, R., Goff, S. B., Kaczala, C. M., Meece, J. L., et al. (1983). Expectancies, values, and academic behaviors. In J. T. Spence (Ed.), Achievement and achievement motivation (pp. 75-146). San Francisco: Freeman.

Elizur, D., \& Beck, I. M. (1994). Gender Differences in Achievement Motive. Journal of 
Psychology, 128, 225-339. http://dx.doi.org/10.1080/00223980.1994.9712712

Fouladchang, M., Marzooghi, R., \& Shemshiri, B. (2009). The effect of gender and grade level differences on achievement goal orientations of Iranian undergraduate students. Journal of Applied Sciences, 9, 968-972.

Guay, F., Marsh, H. W., \& Boivin, M. (2003). Academic self-concept and academic achievement: Developmental perspectives on their causal ordering. Journal of Educational Psychology, 95(1), 124-136.

Kaushik, N., \& Rani, S. (2005). A Comparative study of achievement motivation, home environment and parent child relationship of adolescents. Journal of Psychological research, 49, 189-194.

Linnenbrink, E. A., \& Pintrich, P. R. (2002). Motivation as an enabler for academic success. School Psychology Review, 31, 313-327.

Liu, Q., \& Zhu, X. (2009). Investigation and Analysis on the Achievement Motivations of 278 Senior High School Students. International Journal of Psychological Studies, 1(1), 229-240.

Mandel, H. P., \& Marcus, S. I. (1988). The psychology of under achievement: Differential diagnosis and differential treatment. In I. B. Wiley (Series Ed.), Wiley series on personality processes. New York: John Wiley \& Sons.

Marsh, H. W., \& Ayotte, V. (2003). Do multiple dimensions of self-concept become more differentiated with age? The differential distinctiveness hypothesis. Journal of Educational Psychology, 95(4), 687-706.

Meece, J. L., Glienke, B. B., \& Burg, S. (2006). Gender and motivation. Journal of School Psychology, 44, 351-373.

Nagarathnamma, B., \& V. Thirumal, Rao. (2007). Achievement motivation and Academic Achievement of adolescent Boys and Girls. Indian Psychological Review, 68, 131 136.

Salili, F. (1996). Achievement Motivation: a cross-cultural comparison of British and Chinese students. International Journal of Experimental Educational Psychology, 16(3), 271-27.

Spinath, B., Spinath, F. M., Harlaar, N., \& Plomin, R. (2006). Predicting school achievement from general cognitive ability, self-perceived ability, and intrinsic value. Intelligence, 34, 363-374. 
Upadhyay. S., \& Tiwari.A. (2009). Achievement Motivation across Different Academic Majors. Indian Journal of Social Science Researches, 6(2), 128-132.

Wigfield, A. (1997). Reading motivation: A domain-specific approach to motivation. Educational Psychologist, 32(2), 59-68.

Wigfield, A., \& Eccles, J. S. (2002). Development of achievement motivation. San Diego, CA: Academic Press. 